\title{
Candidatus Rickettsia andeanae, a spotted fever group agent infecting Amblyomma parvum ticks in two Brazilian biomes
}

\author{
Fernanda Aparecida Nieri-Bastos', Marcos Gomes Lopes', Paulo Henrique Duarte Cançado², \\ Giselle Ayres Razera Rossa', João Luiz Horácio Faccini ${ }^{3}$, Solange Maria Gennari' \\ Marcelo Bahia Labruna ${ }^{1} /+$
}

\author{
${ }^{1}$ Faculdade de Medicina Veterinária e Zootecnia, Universidade de São Paulo, São Paulo, SP, Brasil \\ ${ }^{2}$ Embrapa Gado de Corte, Campo Grande, MS, Brasil ${ }^{3}$ Universidade Federal Rural do Rio de Janeiro, Seropédica, RJ, Brasil
}

\begin{abstract}
Adult ticks of the species Amblyomma parvum were collected from the vegetation in the Pantanal biome (state of Mato Grosso do Sul) and from horses in the Cerrado biome (state of Piaui) in Brazil. The ticks were individually tested for rickettsial infection via polymerase chain reaction (PCR) targeting three rickettsial genes, gltA, ompA and ompB. Overall, 63.5\% (40/63) and 66.7\% (2/3) of A. parvum ticks from Pantanal and Cerrado, respectively, contained rickettsial DNA, which were all confirmed by DNA sequencing to be $100 \%$ identical to the corresponding fragments of the gltA, ompA and ompB genes of Candidatus Rickettsia andeanae. This report is the first to describe Ca. R. andeanae in Brazil.
\end{abstract}

Key words: ticks - Amblyomma parvum - Candidatus Rickettsia andeanae

The bacterial genus Rickettsia (Rickettsiales: Rickettsiaceae) includes Gram-negative coccobacilli organisms in obligatory associations with eukaryote cells. A number of Rickettsia species genetically classified into the spotted fever group (SFG) are agents of tick-borne diseases in the world (Parola et al. 2005). In Brazil, the most important SFG agents are Rickettsia rickettsii, the causative agent of Brazilian spotted fever, which is the most deadly rickettsiosis globally (Guedes et al. 2005, Labruna 2009), and the strain Atlantic rainforest, an Rickettsia parkerilike agent that was only recently shown to cause spotted fever in humans (Spolidorio et al. 2010, Silva et al. 2011). Other tick-associated rickettsiae, namely Rickettsia rhipicephali, Rickettsia amblyommii, Rickettsia monteiroi and Rickettsia bellii, have also been reported in Brazil, but have not been associated with human illness (reviewed by Labruna et al. 2011). It is noteworthy that during the last three decades, approximately 10 SFG Rickettsia species or subspecies previously known to infect only ticks were further identified as emerging agents of tick-borne rickettsioses throughout the world (Parola et al. 2005, Shapiro et al. 2010). An outstanding example is $R$. parkeri, which has been known to infect Amblyomma ticks for more than 60 years, but was recognised as a human pathogen only during the last 10 years (Paddock et al. 2004). Based on these findings, it is prudent to consider any new tick-associated Rickettsia species as a potential human pathogen until further studies are conducted.

doi: 10.1590/0074-0276140283

Financial support: FAPESP, CNPq, CAPES

+ Corresponding author: 1abruna@usp.br

Received 28 May 2013

Accepted 27 November 2013
The tick species Amblyomma parvum is distributed from southern Mexico to Argentina (Guglielmone et al. 2003). While the A. parvum adult stage has a preference for parasitising medium to large-sized mammals (ruminants, horses and carnivores), larvae and nymphs seem to prefer small mammals (Aragão 1936, Nava et al. 2008). Recent studies in Argentina and Brazil have indicated that rodents of the genera Galea and Trichomys are important hosts for $A$. parvum sub-adults (Nava et al. 2008, Horta et al. 2011). Of note, the $A$. parvum adult stage is an important human-biting tick in Argentina and Brazil (Guglielmone et al. 2006); therefore, it is a potential pathogen vector for humans.

To evaluate rickettsial infection in $A$. parvum ticks from Brazil, tick specimens were collected in two Brazilian biomes. In the Pantanal biome, free-living ticks were collected by $\mathrm{CO}_{2}$ traps set on the vegetation in the Nhumirim Farm $\left(18^{\circ} 59^{\prime} \mathrm{S} 56^{\circ} 39^{\prime} \mathrm{W}\right)$ at the Nhecolândia Pantanal, state of Mato Grosso do Sul, central-western Brazil, from March 2006-January 2007, as detailed previously (Cançado et al. 2008). In the Cerrado biome, ticks were collected from horses on a farm $\left(04^{\circ} 76^{\prime} 91^{\prime \prime} \mathrm{S}\right.$ $\left.42^{\circ} 58^{\prime} 44^{\prime \prime} \mathrm{W}\right)$ in the municipality of Teresina, state of Piauí (PI), northeastern Brazil, during August 2010. The ticks were preserved in absolute ethanol until they were processed in the laboratory.

Each adult $A$. parvum tick was subjected to DNA extraction by the guanidine isothiocyanate-phenol technique, as previously described (Sangioni et al. 2005). Purified DNA was stored at $-20^{\circ} \mathrm{C}$ until it was used as template for polymerase chain reaction (PCR) amplifications. Five microlitres of each tick DNA template (approximately $500 \mathrm{ng}$ of DNA) was used for PCR using the primers CS-78 (forward) GCAAGTATCGGTGAGGATGTAAT and CS-323 (reverse) GCTTCCTTAAAATTCAATAAATCAGGAT, which amplify a 398-bp fragment of the citrate synthase gene ( $g l t A)$ of, most likely, all 
known Rickettsia species (Labruna et al. 2004). If an expected product was observed following gel electrophoresis, the tick was tested using two other PCR protocols: one targeting a fragment of the rickettsial 190-kDa outer membrane protein gene (ompA) using primers $\mathrm{Rr} 190.70 \mathrm{~F}$ ATGGCGAATATTTCTCCAAAA and Rr190.701R GTTCCGTTAATGGCAGCATCT (Eremeeva et al. 2006) and the other targeting a fragment of the rickettsial 135$\mathrm{kDa}$ outer membrane protein gene (ompB) using primers 120-M59 CCGCAGGGTTGGTAACTGC and 120-807 CCTTTTAGATTACCGCCTAA (Roux \& Raoult 2000). Ten microlitres of each PCR product was electrophoretically separated in a $1.5 \%$ agarose gel stained with ethidium bromide and examined using ultraviolet transillumination. PCR products compatible with the expected band size were purified using ExoSap (USB Corporation, Cleveland, OH, USA ) and sequenced in an automated sequencer (model ABI Prism 310 Genetic, Applied Biosystems, Perkin Elmer, CA, USA) according to the manufacturer's protocol. The partial sequences that were obtained were subjected to BLAST analyses (ncbi. nlm.nih.gov/blast) to determine the closest similarities to other Rickettsia species available in GenBank.

Sixty-three (37 males, 26 females) out of 81 A. parvum adult specimens collected from the vegetation in the Pantanal were tested in this study. From the Cerrado area of PI, 3 A. parvum specimens ( 2 males, 1 female) were collected from three out of 27 examined horses; other tick species (not tested in this study) collected from these horses were Amblyomma cajennense ( 8 adults) and Dermacentor nitens ( 570 adults). The gltA-PCR indicated that $40(63.5 \%)$ A. parvum specimens (20 males, 20 females) from Pantanal and two A. parvum males (66.7\%) from PI were infected by Rickettsia. From these $42 \mathrm{glt} A$-PCR positive ticks, 23 were positive in the ompA-PCR and 17 were also positive in the $о m p B$-PCR. High-quality DNA sequences were obtained from $19 \mathrm{gltA}$-positive ticks, 12 отрA-positive ticks and $11 \mathrm{omp} B$-positive ticks, including the two males from PI. For each rickettsial gene, the sequences from different individual ticks were identical to each other and were also $100 \%$ identical to the corresponding sequences of Candidatus Rickettsia andeanae from the United States of America (USA), Peru and Argentina, (e.g., GU169051, EF451001 for gltA; EU826513, EF372578 for ompA; GU395297, EF451003 for ompB) when submitted to BLAST analyses. The sequences generated in this study have been submitted to GenBank under the accessions KF030931-KF030933.

This study reports the identification of the SFG rickettsial agent $\mathrm{Ca}$. R. andeanae for the first time in Brazil. Taxonomic identification of the agent was confirmed by sequencing fragments of one conserved housekeeping gene $(g l t A)$ and two highly polymorphic outer membrane protein genes (ompA and ompB). Among the 42 ticks that were PCR-positive for the gltA gene, only 23 were positive in the ompA-PCR and 17 in the $o m p B$-PCR. Because fragments of approximately 398, 630 and $820 \mathrm{bp}$ were targeted by the gltA, ompA and $o m p B$-PCR protocols, respectively, the different results obtained with these protocols are possibly related to different PCR sensitivities, as it is well known that the shorter the PCR fragment, the more efficient the PCR reaction (Bustin 2000).
$\mathrm{Ca}$. R. andeanae has been reported to infect ticks in Peru, USA, Argentina and Chile (Blair et al. 2004, Pacheco et al. 2007, Paddock et al. 2010, Abarca et al. 2012). More recently, Luce-Fedrow et al. (2012) and Ferrari et al. (2013) reported evidence for the continuous in vitro cultivation of $\mathrm{Ca}$. R. andeanae. A number of different tick species have been reported to harbour $C a$. R. andeanae in nature. These species include Amblyomma maculatum, Ixodes boliviensis and Rhipicephalus sanguineus in Peru (Blair et al. 2004, Flores-Mendoza et al. 2013), A. maculatum in USA (Paddock et al. 2010, Luce-Fedrow et al. 2012), A. parvum and Amblyomma pseudoconcolor in Argentina (Pacheco et al. 2007, Tomassone et al. 2010) and Amblyomma triste in Chile (Abarca et al. 2012). According to these references, different designations have been given to $C a$. R. andeanae, such as Rickettsia sp. strain Argentina or the rickettsial endosymbiont of $A$. maculatum. Because the DNA sequences representing these different designations were $100 \%$ identical to each other, they are all considered to represent $\mathrm{Ca}$. R. andeanae (Paddock et al. 2010, Luce-Fedrow et al. 2012, Ferrari et al. 2013), which was first reported in Peru by Blair et al. (2004). Because $C a$ R. andeanae-infected ticks were found in distant areas of two Brazilian biomes, it is possible that the distribution of this organism within Brazil is much broader than is reported here.

The majority of the ticks in this study were infected with $C a$. R. andeanae. This finding is in accordance with previous studies that reported that most of the A. parvum ticks from Argentina (69.2\%) were infected with $\mathrm{Ca}$. R. andeanae. However, infection rates by this agent among A. maculatum ticks in USA have been much lower, usually between 1-10\% (Paddock et al. 2010, Jiang et al. 2012). Regardless, the role of $C a$. R. andeanae as a human pathogen is unknown. Because A. parvum is an important human-biting tick in South America (Guglielmone et al. 2006), further studies are needed to evaluate the capacity of $C a$. R. andeanae to be tick transmitted and to infect humans or other vertebrate hosts.

\section{REFERENCES}

Abarca K, López J, Acosta-Jamett G, Lepe P, Soares JF, Labruna MB 2012. A third Amblyommma species and the first tick-borne $R i$ ckettsia in Chile. J Med Entomol 49: 219-222.

Aragão HB 1936. Ixodidas brasileiros e de alguns paizes limitrophes. Mem Inst Oswaldo Cruz 31: 759-843.

Blair PJ, Jiang J, Schoeler GB, Moron C, Anaya E, Cespedes M, Cruz C, Felices V, Guevara C, Mendoza L, Villaseca P, Sumner JW, Richards AL, Olson JG 2004. Characterization of spotted fever group rickettsiae in flea and tick specimens from northern Peru. J Clin Microbiol 42: 4961-4967.

Bustin SA 2000. Absolute quantification of mRNA using real-time reverse transcription polymerase chain reaction assays. $J \mathrm{Mol}$ Endocrinol 25: 169-193.

Cançado PH, Piranda EM, Mourão GM, Faccini JL 2008. Spatial distribution and impact of cattle-raising on ticks in the Pantanal region of Brazil by using the $\mathrm{CO}_{2}$ tick trap. Parasitol Res 103: 371-377.

Eremeeva ME, Bosserman EA, Demma LJ, Zambrano ML, Blau DM, Dasch GA 2006. Isolation and identification of Rickettsia massiliae from Rhipicephalus sanguineus ticks collected in Arizona. Appl Environ Microbiol 72: 5569-5577. 
Ferrari FAG, Goddard J, Moraru GM, Smith WEC, Varela-Stokes AS 2013. Isolation of "Candidatus Rickettsia andeanae" (Rickettsiales: Rickettsiaceae) in embryonic cells of naturally infected Amblyomma maculatum (Ixodida: Ixodidae). J Med Entomol 50: 1118-1125.

Flores-Mendoza C, Florin D, Felices V, Pozo EJ, Graf PC, Burrus RG, Richards AL 2013. Detection of Rickettsia parkeri from within Piura, Peru, and the first reported presence of Candidatus 'Rickettsia andeanae' in the tick Rhipicephalus sanguineus. Vector Borne Zoonotic Dis 13: 505-508.

Guedes E, Leite RC, Prata MCA, Pacheco RC, Walker DH, Labruna MB 2005. Detection of Rickettsia rickettsii in the tick Amblyomma cajennense in a new Brazilian spotted fever-endemic area in the state of Minas Gerais. Mem Inst Oswaldo Cruz 100: 841-845.

Guglielmone AA, Beati L, Barros-Battesti DM, Labruna MB, Nava S, Venzal JM, Mangold AJ, Szabo MP, Martins JR, GonzalezAcuna D, Estrada-Pena A 2006. Ticks (Ixodidae) on humans in South America. Exp Appl Acarol 40: 83-100.

Guglielmone AA, Estrada-Peña A, Keirans JE, Robbins RG 2003. Ticks (Acari: Ixodida) of the Neotropical zoogeographic region, Universiteit Utrecht/J Bovy-Verbeek, Utrecht, 173 pp.

Horta MC, Nascimento GF, Martins TF, Labruna MB, Machado LCP, Nicola PA 2011. Ticks (Acari: Ixodida) parasitizing free-living wild animals in the Caatinga biome in the state of Pernambuco, northeastern Brazil. Syst Appl Acarol 16: 207-211.

Jiang J, Stromdahl EY, Richards AL 2012. Detection of Rickettsia parkeri and Candidatus 'Rickettsia andeanae' in Amblyomma maculatum Gulf Coast ticks collected from humans in the United States. Vector Borne Zoonotic Dis 12: 175-182.

Labruna MB 2009. Ecology of Rickettsia in South America. Ann N Y Acad Sci 1166: 156-166.

Labruna MB, Mattar S, Nava S, Bermudez SM, Dolz G, Abarca K, Romero L, Oteo J, Zavala-Castro J 2011. Rickettsiosis in Latin America, Caribbean, Spain and Portugal. Rev MVZ Cordoba 16: 2435-2457.

Labruna MB, Whitworth T, Horta MC, Bouyer DH, Mcbride JW, Pinter A, Popov V, Gennari SM, Walker DH 2004. Rickettsia species infecting Amblyomma cooperi ticks from an area in the state of São Paulo, Brazil, where Brazilian spotted fever is endemic. J Clin Microbiol 42: 90-98.

Luce-Fedrow A, Wright C, Gaff HD, Sonenshine DE, Hynes WL, Richards AL 2012. In vitro propagation of Candidatus Rickettsia andeanae isolated from Amblyomma maculatum. FEMS Immunol Med Microbiol 64: 74-81.
Nava S, Mangoldi AJ, Guglielmone AA 2008. Aspects of the life cycle of Amblyomma parvum (Acari: Ixodidae) under natural conditions. Vet Parasitol 156: 270-276.

Pacheco RC, Moraes-Filho J, Nava S, Brandao PE, Richtzenhain LJ, Labruna MB 2007. Detection of a novel spotted fever group rickettsia in Amblyomma parvum ticks (Acari: Ixodidae) from Argentina. Exp Appl Acarol 43: 63-71.

Paddock CD, Fournier PE, Sumner JW, Goddard J, Elshenawy Y, Metcalfe MG, Loftis AD, Varela-StokesA 2010. Isolation of Rickettsia parkeri and identification of a novel spotted fever group Rickettsia sp. from Gulf Coast ticks (Amblyomma maculatum) in the United States. Appl Environ Microbiol 76: 2689-2696.

Paddock CD, Summer JW, Comer JA, Zaki SR, Goldsmith CS, Goddard J, Mclellan SLF, Tamminga CL, Ohl CA 2004. Rickettsia parkeri: a newly recognized cause of spotted fever rickettsiosis in the United States. Clin Infect Dis 38: 805-811.

Parola P, Davoust B, Raoult D 2005. Tick and flea-borne rickettsial emerging zoonoses. Vet Res 36: 469-492.

Roux V, Raoult D 2000. Phylogenetic analysis of members of the genus Rickettsia using the gene encoding the outer membrane protein rOmpB (ompB). Int J Syst Evol Microbiol 50: 1449-1455.

Sangioni LA, Horta MC, Vianna MCB, Gennari SM, Soares RM, Galvão MAM, Schumaker TTS, Ferreira F, Vidotto O, Labruna MB 2005. Rickettsial infection in animals and Brazilian spotted fever endemicity. Emerg Infect Dis 11: 265-270.

Shapiro MR, Fritz CL, Tait K, Paddock CD, Nicholson WL, Abramowicz KF, Karpathy SE, Dasch GA, Sumner JW, Adem PV, Scott JJ, Padgett KA, Zaki SR, Eremeeva ME 2010. Rickettsia 364D: a newly recognized cause of eschar-associated illness in California. Clin Infect Dis 50: 541-548.

Silva N, Eremeeva ME, Rozental T, Ribeiro GS, Paddock CD, Ramos EA, Favacho AR, Reis MG, Dasch GA, de Lemos ER, Ko AI 2011. Eschar-associated spotted fever rickettsiosis, Bahia, Brazil. Emerg Infect Dis 17: 275-278.

Spolidorio MG, Labruna MB, Mantovani E, Brandao PE, Richtzenhain LJ, Yoshinari NH 2010. Novel spotted fever group rickettsiosis, Brazil. Emerg Infect Dis 16: 521-523.

Tomassone L, Nuñez P, Ceballos LA, Gürtler RE, Kitron U, Farber M 2010. Detection of "Candidatus Rickettsia sp. strain Argentina" and Rickettsia bellii in Amblyomma ticks (Acari: Ixodidae) from Northern Argentina. Exp Appl Acarol 52: 93-100. 